\title{
The Development of Lesson Plan of Inquiry Contextual Learning to Improve the Higher Order Thinking Skill Students at Microbiology
}

\author{
Hasruddin, Fauziyah Harahap, Mahmud \\ Postgraduate Medan State University, Medan, Indonesia \\ Email: hasruddin_lbsmdn@yahoo.com
}

How to cite this paper: Hasruddin, Harahap, F. and Mahmud (2017) The Development of Lesson Plan of Inquiry Contextual Learning to Improve the Higher Order Thinking Skill Students at Microbiology. Open Access Library Journal, 4: e3943. https://doi.org/10.4236/oalib.1103943

Received: September 15, 2017

Accepted: November 11, 2017

Published: November 14, 2017

Copyright ( 2017 by authors and Open Access Library Inc.

This work is licensed under the Creative Commons Attribution International License (CC BY 4.0).

http://creativecommons.org/licenses/by/4.0/

\begin{abstract}
This research aims to know the effectiveness of the implementation lesson plan inquiry contextual learning to improve higher order thinking skill of students in the lecture for microbiology. The lesson plan that was developed in the form of inquiry contextual learning model. Research and development includes three stages of research: study of the introduction, development of microbiology lesson plan, and free trial test implementation of lesson plan. Research instrument used to collect the data consists of sheets of validation by the material, design experts, and linguists, and test descriptions to measure higher order thinking ability. The data analysis used descriptive statistics. A preliminary study undertaken to 40 students who are currently attending microbiology stated that the need for planning learning microbiology devices applying active learning process based on inquiry contextual. Learning outcomes during this time is more dominant in the ability of low-level thinking included in the category of knowledge and understanding, it is necessary to design a microbiological learning that directs the thinking ability of high-level students, namely application, analysis, evaluation, and creation. The results of the trial were limited to 34 students of the experimental class and 35 control-class students found that the research hypothesis was accepted, meaning that the contextual inquiry-based microbiology learning tools had higher-order thinking than the traditional class.
\end{abstract}

\section{Subject Areas}

Education

\section{Keywords}

Microbiology, Higher Order Thinking Skill, Lesson Plan, Contextual Inquiry 


\section{Introduction}

The teacher used contextual teaching and learning in their instruction to follow their student can connect new information with prior knowledge and experience [1]. Contextual inquiry can lead students to think in high-order [2], science process skills [3], critical thinking [1], and scientific attitudes [4]. The Good learning needs a good planning [5] as to achieve the goal of learning successfully [6]. Therefore, planning the implementation of learning needs to be reviewed and revised for better improvement, which is useful for measuring student progress and learning process [7]. Thus, the learning process can lead to active learning that can enhance students' knowledge, attitude, and thinking [8] [9] [10], and problem solving activity [11].

The acquisition of knowledge, values, attitudes, thinking processes, and creativity has been seen as a worthy educational objectives [12] including the purpose of microbiology, because basically microbiology materials should be applicable to students in daylilife. Learning should be able to give students the freedom to think [5]. Freedom of the thingking requires understanding oneself, one's actions, and one's surroundings. The 10 rational powers of recalling, imagining, classifying, generalizing, comparing, evaluating, analyzing, deducing, and infering. Without rational powers, people must accept the ideas, beliefs, and attitudes of others. The problems are how can instruction be designed and implemented to help students become better thinkers [12].

Students in learning of microbiology with active learning process. Learning should be well designed with pay more attention to the cognitive, affective, and psychomotor level. The ability to be achieved in learning should be high-order thinking skills. A workable way of learning to achieve the goal of higher-order thinking is by using contextual inquiry learning. In line with [1] opinion; and [13] that learning by using contextual inquiry can bring students to practice high-order thinking skills. [14] suggests that learning goals are designed that can consider knowledge, values, and attitudes.

In microbiology materials, students learn concepts, principles, and metacognition comprehensively. Microbiological materials studied by students as prospective teachers such as the world of bacteria, viruses, fungi, algae, bacterial classification, bacterial staining, bacterial habitat, bacterial role in human life. Students' skills in studying microbiology, it is expected that they are able to apply their knowledge and intelligently apply it in real life. Bacteria are everywhere, and humans must be able to utilize bacteria for the well-being of their lives.

How can we teach microbiology so that students develop scientific thinking skills, freedom of mind, scientific literacy, and higher order thinking? Teaching should allow students to participate in inquiry contextual that is, in the knowledge construction process. Importantly, as we shall see, high order thinking skills play a key role in learning microbiology content. Thus, teaching in ways that help students develop their high order thinking skills will pay off in 
terms of better content learning and better performance [15] and students worked in groups to plan, set up, and carry out their own investigation [16].

This research produces the development product in the form of planning of microbiology based on inquiry contextuallearning. Another development products is authentic scoring sheets. So that the problem to be answered in this research is how the effectiveness of microbiological learning tools development based on inquiry contextual to students' high thinking ability. The results of this study are expected as an effort to improve the implementation plan of learning that is oriented on active learning and empower students' thinking ability. In the future, the high order thinking skills will be very important in winning the job competition, so it will support the success of their careers in the future.

\section{Research Methods}

This research was conducted in Department of Biology State University of Medan at North Sumatra. This development research used the subject of research as many as 40 students of Biology Education as a preliminary research. Two peopple of experts from the field of study as validators were concluded, 2 design learning experts, and also 2 from the linguist. Subjects for the limited group were 9 students of biology education, and the resulting product trial used as many as 34 students for the experimental class and 35 people for the control class. The experimental class was treated by applying contextual inquiry learning while the control class was applied to traditional learning.

The model for developing a contextual inquiry learning plan which consists of study 1) preliminary study, 2) planning, and 3) validation and piloting. In the preliminary study stage, needed analysis and identification of the competencies and basic problems faced by students in microbiology learning. Techniques used at this stage were surveys, interviews, and documentation studies to examine the microbiological learning process so far. Furthermore, the literature review to review the theory of learning relevant to future demands so that the learning plan was obtained in accordance with needed analysis.

The planning stage in this research was to arrange learning tools, such as learning implementation plan, lecture contract, instructional media, student worksheet, and evaluation or assessment of learning in accordance with contextual inquiry learning model.The preparation of lecturing tools was in line with the current curriculum in the Biology Department, Indonesian National Qualification Framework, which took into account the content standards, process standards, infrastructure standards, and evaluation standards.

Planning the microbiology learning deviced by developing a contextual inquiry learning model. Measured learning steps of the mercury consist of: attention, presenting problems, formulating hypotheses, collecting data, formulating conclusions, and reflecting problems. Implementation of learning uses contextual learning that accommodates 8 components: making meaningful connections, independent learning, meaningful work, collaboration, critical and 
creative thinking, helping individuals to grow and develop, achieve high standards, and use authentic judgment. By combining this contextual inquiry invited students to link campus tasks such as routine tasks, critical analysis of material from textbooks, critical analysis of research results from research journals, ideas for papers, mini-research, andassignments based on project.

Selection of materials or lecture materials in accordance with the competence to be achieved. Assigned lecture topics based on time allocation and availability of media, worksheets, and selection of cognitive, affective, and psychomotor ability assessment forms from students.Validation and testing stages were carried out by conducting a formative evaluation. Formative evaluation was conducted to collect information, description, data executed by the developer during process, procedure, program or product was in progress or developed. Formative evaluation was also carried out to assess product progress and obtain improvements to support increased effectiveness. Formative evaluation involves experts in their respective fields.Expert validation in this study used 2 microbiologists obtained from universities with microbiology doctoral qualifications. The learning implementation plan was also validated by 2 qualified instructional design experts of educational technology professors level, and also involveed 2 qualified doctoraloflinguist. The revised results of this expert validation were, the product of the development that will proceed in the pilot phase.

The pilot phase was done to know the effectiveness ofusing of microbiology learning implementationplan. Implementation of trials included testing individual material prototypes, small group trials, and field trials. Individual trials were conducted to get initial input on the design product. Individual trials were conducted for 3 students, one low-skilled student, one medium-skilled student, and one highly skilled student in microbiology. After individual trials conducted, the revisions of materials, media, and design of implementation plans based on contextual inquiry was done based on input from 3 students.

Small group trials were conducted for9 students consisting of 3 students with low ability, 3 medium-skilled students, and 3 high-ability students in the field of microbiology. The results of this limited group trial were used to revise the implementation plan learning based on contextual inquiry.

Field trials involved 25 subjects as a research subject. In this field trial the first test was done early, the process of teaching and learning activities, and the final test. The test results were used to perform the data analysis so that it can determine the effective implementation of learning plan to improve students' high thinking ability. The revision of the learning implementation plan was carried out after all the developed devices had been tested. Revision activities were carried out to improve products based on input and assessment from experts and field trial inputs.

The research data were collected through high-order thinking skills. The test consists often questions in the form of a test essay. Prior to use the test 
instrument description was first validatedboth content validation, construction validation, and empirical validation. Similarly, test reliability test was done. Data relating to student responses used questionnaires and interviews conducted at the end of learning.Data analysis technique used in this research was descriptive analysis.

The analitical techniques that was used to analyze the validation of the implementation of the learning plan used descriptive qualitative, by looking at the feasibility assessment of the implementation plan of learning from the results of the study. Material expert validators, learning descriptions, and linguists would answer the questions by checking the list on a scale of 1 - 4. Then calculated the percentage score of the lesson plan implementation.

Analysis of student responses to contextual inquiry learning activities on microbiology lectures using percentage techniques. To find out the effectiveness ofproduct implementation plan of learning resulted in this research, then tested in two different class. One class useed the developed product and one more class using the traditional learning implementation plan. Measurement of students' high-level thinking skills through initial and final tests used the problems contained in the lesson plan. The difference in average high-ability thinking in the two different groups was analyzed by t-test at a significance level of $5 \%$ using SPSS version 22.0.

\section{Research Result}

\subsection{Needing Analysis and Identification of Material}

Based on the study on the implementation of microbiology in Biology Department of Medan State University that the fundamental problem was that the learning has not been using inquiry contextual model. Students were alreadyinvolved in the learning process actively but student involvement was still not optimal. Evidently there were some students who were just waiting for their friends in conducting investigation activities. Observation of the inquiry process that hasd been done, there were some learning steps that had not been implemented properly, such as formulating hypotheses and designing experiments. Students awere familiar with the steps these were written in detail such as recipes and are less challenging. Measurements were done more to low-level thinking skills such as memory and understanding.

To overcome these fundamental problems, it was necessary to develop a learning implementation plan that can improve students' high-level thinking skills in microbiology lectures. One of the learning models that can improve higher order thinking was a contextual inquiry model. This is intended to give students the opportunity to construct their knowledge. Students' thinking skills need to be directed to improve higher order thinking skills. For that need to make improvements and development oflecture implementation plans, lecture contracts, instructional media, student worksheets, and authentic assessment.

Topics covered were microbiological development, microbial classification, 
bacteria, fungi, fungi, virus, microbial habitat, microbial physiology, microbial growth, microbial measurement, microbial genetics, water microbiology, soil microbiology, food microbiology, microbiology of agriculture, health microbiology, industrial microbiology, and environmental microbiology.

\subsection{Validation Description}

The validation result by 2 experts of microbiology material conducted by the lecturer qualified doctoral, obtained data as shown in Table 1 below.

The validation result of 2 design learning experts conducted by professors qualified professors, obtained data as shown in Table 2.

The validation results of 2 linguists conducted by professors qualified professors, obtained data as shown in Table 3.

The results of individual trials to 3 students who have ever received a microbiology lecture, obtained data as contained in Table 4 .

The results of small group trials to 9 students who have ever received microbiology lectures, obtained data as shown in Table 5.

Results of field trials to 25 students who have ever received microbiology lectures, obtained data as shown in Table 6.

\subsection{Effectiveness of Lesson Plans}

The results of product effectiveness test of contextual learning implementation

Table 1. Results of the validation of the implementation plan for learning by expert of microbiology.

\begin{tabular}{|c|c|c|c|c|c|}
\hline $\begin{array}{c}\text { Assessment } \\
\text { Aspect }\end{array}$ & $\begin{array}{l}\text { Assessment } \\
\text { Indicator }\end{array}$ & Assessment items & Score & Average (\%) & Criteria \\
\hline \multirow{8}{*}{$\begin{array}{c}\text { Feasibility of } \\
\text { Content }\end{array}$} & \multirow{8}{*}{$\begin{array}{l}\text { Quality of Learning } \\
\text { Materials }\end{array}$} & 1) Depth of matter & 4 & 100 & Very Good \\
\hline & & 2) Accuracy of material coverage & 3 & 75 & Good \\
\hline & & 3) Logical material & 3 & 75 & Good \\
\hline & & 4) The precision of material sequence & 4 & 100 & Very Good \\
\hline & & 5) Clarity of learning objectives & 2 & 50 & Deficient \\
\hline & & 6) Conformity with the curriculum & 3 & 75 & Good \\
\hline & & 7) Ease of understanding & 3 & 75 & Good \\
\hline & & 8) The truth of the concept & 4 & 100 & Very Good \\
\hline \multirow{3}{*}{$\begin{array}{l}\text { Contextual } \\
\text { Inquiry Model }\end{array}$} & \multirow{3}{*}{$\begin{array}{l}\text { Learning delivery } \\
\text { system }\end{array}$} & 9) Conformity with contextual inquiry & 3 & 75 & Good \\
\hline & & 10) Student involvement in learning activities & 3 & 75 & Good \\
\hline & & 11) Encourage students to think freely & 3 & 75 & Good \\
\hline \multirow{5}{*}{ Delivery Quality } & \multirow{5}{*}{$\begin{array}{l}\text { Learning Strategy } \\
\text { Quality }\end{array}$} & 12) IntroductionQuality & 4 & 100 & Very Good \\
\hline & & 13) FeedbackQuality & 3 & 75 & Good \\
\hline & & 14) Time of presentation & 3 & 75 & Good \\
\hline & & 15) ReflectionQuality & 3 & 75 & Good \\
\hline & & 16) Exercise question Quality & 4 & 100 & Very Good \\
\hline \multicolumn{3}{|c|}{ Obtaining Score Result (f) } & 52 & 81.25 & Very Good \\
\hline
\end{tabular}


Table 2. Results of the validation of learning implementation plan by education technology experts.

\begin{tabular}{|c|c|c|c|c|c|}
\hline $\begin{array}{l}\text { Assessment } \\
\text { Aspect }\end{array}$ & $\begin{array}{l}\text { Assessment } \\
\text { Indicator }\end{array}$ & Assessment items & Score & Average (\%) & Criteria \\
\hline \multirow{8}{*}{$\begin{array}{c}\text { Feasibility of } \\
\text { Content }\end{array}$} & \multirow{8}{*}{$\begin{array}{c}\text { Quality of Learning } \\
\text { Materials }\end{array}$} & 1) Depth of matter & 3 & 75 & Good \\
\hline & & 2) Accuracy of material coverage & 3 & 75 & Good \\
\hline & & 3) Logical material & 3 & 75 & Good \\
\hline & & 4) The precision of material sequence & 3 & 75 & Good \\
\hline & & 5) Clarity of learning objectives & 4 & 100 & Very Good \\
\hline & & 6) Conformity with the curriculum & 3 & 75 & Good \\
\hline & & 7) Ease of understanding & 4 & 100 & Very Good \\
\hline & & 8) The truth of the concept & 4 & 100 & Very Good \\
\hline \multirow{3}{*}{$\begin{array}{l}\text { Contextual } \\
\text { Inquiry Model }\end{array}$} & \multirow{3}{*}{$\begin{array}{l}\text { Learning delivery } \\
\text { system }\end{array}$} & 9) Conformity with contextual inquiry & 3 & 75 & Good \\
\hline & & $\begin{array}{l}\text { 10) Student involvement in learning } \\
\text { activities }\end{array}$ & 3 & 75 & Good \\
\hline & & 11) Encourage students to think freely & 3 & 75 & Good \\
\hline \multirow{5}{*}{ Delivery Quality } & \multirow{5}{*}{$\begin{array}{l}\text { Learning Strategy } \\
\text { Quality }\end{array}$} & 12) IntroductionQuality & 4 & 100 & Very Good \\
\hline & & 13) FeedbackQuality & 4 & 100 & Very Good \\
\hline & & 14) Time of presentation & 3 & 75 & Good \\
\hline & & 15) ReflectionQuality & 2 & 50 & Deficient \\
\hline & & 16) Exercise question Quality & 4 & 100 & Very Good \\
\hline \multicolumn{3}{|c|}{ Obtaining Score Result (f) } & 53 & 82.81 & Very Good \\
\hline
\end{tabular}

Table 3. Validation results of a lesson learned lesson plan.

\begin{tabular}{|c|c|c|c|c|}
\hline $\begin{array}{c}\text { Assessment } \\
\text { Aspect }\end{array}$ & $\begin{array}{l}\text { Assessment } \\
\text { Indicator }\end{array}$ & Assessment items & Score & Average (\%) \\
\hline \multirow{8}{*}{ Language Usage } & 1) Accuracy of sentence structure & 3 & 75 & Good \\
\hline & 2) Effectiveness of sentences & 4 & 100 & Very Good \\
\hline & 3) Clarity of language in matter & 3 & 75 & Good \\
\hline & 4) Clarity of sentences & 4 & 100 & Very Good \\
\hline & 5) Interesting style of language & 4 & 100 & Very Good \\
\hline & 6) Using language rules & 4 & 100 & Very Good \\
\hline & 7) Ease of understanding & 3 & 75 & Good \\
\hline & 8) Clarity of the meaning of language & 4 & 100 & Very Good \\
\hline \multirow{3}{*}{ Language Accuracy } & 9) Clarity of letters & 3 & 75 & Good \\
\hline & 10) The symbol clarity used & 3 & 75 & Good \\
\hline & 11) Clarity of command & 4 & 100 & Very Good \\
\hline \multirow{5}{*}{$\begin{array}{c}\text { Conformity of } \\
\text { student } \\
\text { development }\end{array}$} & 12) The use of punctuation & 4 & 100 & Very Good \\
\hline & 13) Conformity of students' thinking level & 3 & 75 & Good \\
\hline & 14) Can stimulate the imagination & 3 & 75 & Good \\
\hline & 15) Can inspire & 2 & 50 & Deficient \\
\hline & 16) Build a way of thinking & 3 & 75 & Good \\
\hline Obtaining Score (f) & & 54 & 84.38 & Very Good \\
\hline
\end{tabular}


Table 4. Individual of student response to microbiology learning implementation plan.

\begin{tabular}{cccc}
\hline No & Average Score $(\mathrm{SRr})$ & Criteria & Percentage (\%) \\
\hline 1 & $3.00<\mathrm{SRr} \leq 4.00$ & Very Positive & 22.52 \\
2 & $2.00<\mathrm{SRr} \leq 3.00$ & Positive & 79.48 \\
3 & $1.00<\mathrm{SRr} \leq 2.00$ & Negative & 0 \\
\hline
\end{tabular}

Table 5. Small group of student response to the microbiology learning implementation plan.

\begin{tabular}{cccc}
\hline No & Average Score $(\mathrm{SRr})$ & Criteria & Percentage $(\%)$ \\
\hline 1 & $3.00<\mathrm{SRr} \leq 4.00$ & Very Positive & 28.26 \\
2 & $2.00<\mathrm{SRr} \leq 3.00$ & Positive & 71.74 \\
3 & $1.00<\mathrm{SRr} \leq 2.00$ & Negative & 0 \\
\hline
\end{tabular}

Table 6. Field trials of student response to microbiology learning implementation plan.

\begin{tabular}{cccc}
\hline No & Average Score (SRr) & Criteria & Percentage (\%) \\
\hline 1 & $3.00<\mathrm{SRr} \leq 4.00$ & Very Positive & 24.58 \\
2 & $2.00<\mathrm{SRr} \leq 3.00$ & Positive & 75.42 \\
3 & $1.00<\mathrm{SRr} \leq 2.00$ & Negative & 0 \\
\hline
\end{tabular}

Table 7. Table t test gain score.

\begin{tabular}{|c|c|c|c|c|c|c|c|c|c|c|}
\hline \multicolumn{11}{|c|}{ Independent Sample Test } \\
\hline & & \multicolumn{2}{|c|}{$\begin{array}{c}\text { Levene's Test } \\
\text { for Equality of } \\
\text { Variances }\end{array}$} & \multicolumn{7}{|c|}{ t-test for Equality of Means } \\
\hline & & \multirow[t]{2}{*}{$\mathrm{F}$} & \multirow[t]{2}{*}{ Sig. } & \multirow[t]{2}{*}{$\mathrm{t}$} & \multirow[t]{2}{*}{$\mathrm{df}$} & \multirow[t]{2}{*}{$\begin{array}{c}\text { Sig. } \\
\text { (2-tailed) }\end{array}$} & \multirow[t]{2}{*}{$\begin{array}{c}\text { Mean } \\
\text { Difference }\end{array}$} & \multirow[t]{2}{*}{$\begin{array}{l}\text { Std. Error } \\
\text { Difference }\end{array}$} & \multicolumn{2}{|c|}{$\begin{array}{c}\text { 95\% Confidence } \\
\text { Interval of the } \\
\text { Difference }\end{array}$} \\
\hline & & & & & & & & & Lower & Upper \\
\hline \multirow[b]{2}{*}{$\begin{array}{l}\text { Gain } \\
\text { Score }\end{array}$} & $\begin{array}{c}\text { Equal } \\
\text { variances } \\
\text { assumed }\end{array}$ & 0.548 & 0.464 & 4.722 & 67 & 0.000 & 11.872 & 3.275 & 6.304 & 17.26 \\
\hline & $\begin{array}{c}\text { Equal } \\
\text { variances } \\
\text { not } \\
\text { assumed }\end{array}$ & & & 4.722 & 66.72 & 0.000 & 11.872 & 3.275 & 6.237 & 17.16 \\
\hline
\end{tabular}

plan on microbiology lecture by using $t$ test with SPSS version 22.0 is obtained data as shown in Table 7.

Based on Table 7 displays data on equal variances assumed there is a difference at the $5 \%$ level where $t=4.722 ; \mathrm{p} \leq 0.05$. The experimental group had significant changes compared to the control group. This means that the treatment given to the experimental group has posstest value for higher-order thinking is better to use contextual inquiry-based learning plan than the traditional. 


\section{Discussion}

The results of needing analysis showed that its really important to fix the implementation plan of learning that can lead to active learning to improve the students' higher order thinking. The learning model was decided using a inquiry contextual learning model. The reason for using contextual inquirybased learning model, because this model can make student diligently ask, doing investigation, and building ability of thinking. This is in line with the opinion of [17] which states that contextual inquiry is explored by discovery, discovery, and invention [18].

Planning a good learning in it there is a well-defined objectives. Learning objectives should lead to competencies that students want to achieve in learning. In the purpose of learning should be formulated comprehensively achievement of learning. [19] suggests that learning objectives should be to achieve knowledge, values, attitudes, thingking processes, and creativity. Similarly, according to [5] which states that the formulation of learning objectives to meet student expectations, so that the formulation of goals arranged into a series of realistic. [16] states that learning goals are crucial to achieving special skills or competencies.

The plan for implementing the microbiological lesson prepared is adapted to the current syllabus. In this study the material is prepared based on needs analysis to improve students' high-order thinking skills. In line with the opinion of [8] which states that the preparation of the syllabus to be careful that still pay attention to the intellectual focus of students. [16] also states that the syllabus is composed of titles, text boxes, lists with symbols, graphs to emphasize important information, so that students can follow the lectures logically and chronologically following the sequence of topics covered.The product of development in this research resulted in a proper learning implementation plan used to measure students' high thinking ability. High student's thinking ability is trained because it can assist students in applying it to problems outside school. For that learning used is contextual inquiry learning. This is in line with [9] who argue that Contextual Teaching and Learning has been defined here as a way of introducing content. learn, and to construct new knowledge from the analysis and synthesis of this learning process.

\section{Conclusion}

Based on the result of the research, the conclusion of this research are: 1) Implementation of inquiry contextual learning plan is very appropriate to improve students' higher order thinking ability in microbiology at the Department of Biology of the State University of Medan, and 2) Higher order thinking ability for students who are taught with inquiry contextual learning higher than traditional learning in microbiology.

\section{Acknowledgements}

Spoken to the Directorate of Research and Community Service, Directorate 
General for Research and Development of the Ministry of Research, Technology and Higher Education, in accordance with the Research Contract, Number: 045A/UN33.8/LL/2017, dated April 5, 2017.

\section{References}

[1] Johnson, E.B. (2002) Contextual Teaching and Learning: What It Is and Why It Is Here to Stay. Corwin Press, Inc., Thousands Oaks.

[2] Crawford, L.M. (2001) Teaching Contextually: Research, Rationale, and Techniques for Improving Student Motivation and Achievement. CCI Publishing, Inc., Texas.

[3] Abdi, A. (2014) The Effect of Inquiry Based Learning Method on Students Academic Achievement in Science Course. Universal Journal of Educational Research, 2, 37-41.

[4] Kristanti, A.A., Sunarno, W. and Suparmi (2012) Pembelajaran IPA dengan Inkuiri Bebas Termodifikasi Menggunkan Lab Riildan Lab Virtual Ditinjaudari Kemampuan Berpikirdan Gaya Belajar. Jurnal Inkuiri, 1, 106-114.

[5] Davis, B.G. (2013) Tools for Teaching. Rajawali Press, Jakarta.

[6] Kalman, C.S. (2008) Successful Science and Engineering Teaching: Theoretical and Learninf Prespectives. Springer, New York. https://doi.org/10.1007/978-1-4020-6910-9

[7] Donnelly, R. and Fitzmaurice, M. (2005) Designing Modules for Leraning. In: O'Neill, G., Moore, S. and McMullin, B., Eds., Emerging Issues in the Practice of University Learning and Teaching, All Ireland Society for Higher Education, Dublin.

[8] Fry, H., Ketteridge, S. and Marshall, S. (2003) A Handbook for Teaching and Learning in Higher Education: Enhancing Academic Practice. 2nd Edition, Routledge Falmer, New York.

[9] Ramsden, P. (2003) Learning to Teach in Higher Education. 2nd Edition, Routledge Falmer, New York.

[10] Suskie, L.A. (2004) Assessing Students Learning: A Common Sense Guide. Anker, Bolton.

[11] Flick, L.B. and Ledermen, N.G. (2006) Scientific Inquiry and Nature of Science. Springer, Netherlands.

[12] Lawson, A.E. (2010) Teaching Inquiry Science. SAGE Publications. Inc., London.

[13] Sears, S.J. (2002) Contextual Teaching and Learning (A Primer for Effective Instruction). Phi Delta Kappa Educational Foundation, Bloomington, Indiana.

[14] Gormally, C., Brickman, R., Hallar, B. and Amstrong, N. (2009) Effects of Inquiry Based Learning on Students, Science Literacy Skills and Confidence. International Journal Scholarship of Teaching and Learning, 3, 24-32. https://doi.org/10.20429/ijsotl.2009.030216

[15] Grunert O’Brein, J., Millis, B.J. and Cohen, M.W. (2008) The Course Syllabus. Josey-Bass, San Fransisco.

[16] Race, P. (2007) The Lecturer's Toolkit. Routledge, London.

[17] Hudson, C. and Whisler, V.R. (2016) Contextual Teaching and Learning for Practitioners Clemente. Systemics, Cybernetics and Informatics, 6, 54-58.

[18] Lang, J.M. (2008) On Course: A Week By-Week Guide to Your First Semester of College Teaching. Harvard University Press, Cambridge.

[19] Nelson, L.B. (2007) The Graphics Syllabus and the Outcomes Map: Communicating Your Course. Jossey-Bass, San Fransisco. 
Submit or recommend next manuscript to OALib Journal and we will provide best service for you:

- Publication frequency: Monthly

- 9 subject areas of science, technology and medicine

- Fair and rigorous peer-review system

- Fast publication process

- Article promotion in various social networking sites (LinkedIn, Facebook, Twitter, etc.)

- Maximum dissemination of your research work

Submit Your Paper Online: Click Here to Submit

Or Contact service@oalib.com 